Original Article

\title{
Assessment of caregiver burden with elderly having cognitive deficit*
}

\author{
Avaliação da sobrecarga em cuidadores de idosos com deficit cognitivo
}

Evaluación de la sobrecarga en cuidadores de ancianos con déficit cognitivo

\author{
Aline Cristina Martins Gratao ${ }^{1}$, Luana Flávia da Silva Talmelli², Vanderlei José Haas ${ }^{3}$, \\ Sueli Marques ${ }^{4}$, Luciana Kusumota ${ }^{5}$, Rosalina Aparecida Partezani Rodrigues ${ }^{6}$
}

\begin{abstract}
To characterize the elderly with cognitive déficit, and family caregivers who live in the urban communit,y and to identify the caregiver burden. Methods: An observational, cross-sectional study, conducted between January and July 2009. Seventy elderly (aged 65 and older) were assessed for cognitive deficit using the Mini Mental State Examination (MMSE); their 70 caregivers were evaluated by the Zarit Burden Scale (ZBS) and the Self Reporting Questionnaire (SRQ). The data were entered and validated by double entry in the MS Excel Program, and were analyzed using SPSS software, version 15.0. Results: Of the caregivers, 47.1\% were children. We obtained a mean for the ZBS of 30.3 ( \pm 17.3 ) and 6.2 ( \pm 3.2 ) for the SRQ, p $<0.05$, correlating lower scores of the MMSE with high scores on ZBS and SRQ. Conclusions: Cognitive deficit of the elderly was a predictive factor for burden and emotional distress of caregivers. Knowing the reduction of cognitive capacity related to caregiver burden is essential for preserving caregiver health.
\end{abstract}

Keywords: Aged; Caregivers; Stress, psychological; Cognition disorders

\section{RESUMO}

Objetivos: Caracterizar idosos com deficit cognitivo e cuidadores familiares que vivem na comunidade urbana e identificar a sobrecarga dos cuidadores. Métodos: Estudo observacional, seccional, conduzido entre janeiro e julho de 2009 com 70 idosos com 65 anos ou mais de idade com deficit cognitivo avaliados por meio do miniexame do Estado Mental (MEEM) e com seus 70 cuidadores avaliados pela Escala de Sobrecarga de Zarit (ESZ) e o Self Reporting Questionaire (SRQ). Os dados, digitados e validados por dupla entrada no Programa Excel foram analisados no aplicativo SPSS, versão 15.0. Resultados: Dos cuidadores, 47,1\% eram filhos (as). Obteve-se média para Zarit, 30,3( $\pm 17,3)$ e 6,2( $\pm 3,2)$ para SRQ, $\mathrm{p}<0,05$, correlacionando baixos escores de MEEM com altos escores da ZBI e SRQ. Conclusões: O deficit cognitivo desses idosos foi fator preditivo para sobrecarga e desconforto emocional de seus cuidadores. Conhecer a redução da capacidade cognitiva relacionada à sobrecarga do cuidador é indispensável para preservar sua saúde.

Descritores: Idoso; Cuidadores; Estresse psicológico; Transtornos cognitivos.

\section{RESUMEN}

Objetivos: Caracterizar ancianos con déficit cognitivo y cuidadores familiares que viven en la comunidad urbana e identificar la sobrecarga de los cuidadores. Métodos: Estudio observacional, seccional, conducido entre enero y Julio de 2009 con 70 ancianos de 65 años o más de edad con déficit cognitivo evaluados por medio del miniexamen del Estado Mental (MEEM) y con sus 70 cuidadores evaluados por la Escala de Sobrecarga de Zarit (ESZ) y el Self Reporting Questionaire (SRQ). Los datos, digitados y validados por doble entrada en el Programa Excel fueron analizados en el aplicativo SPSS, versión 15.0. Resultados: De los cuidadores, 47,1\% eran hijos (as). Se obtuvo la media para Zarit, 30,3( $\pm 17,3$ ) y $6,2( \pm 3,2)$ para SRQ, p $<0,05$, correlacionando bajos scores de MEEM con altos scores de la ZBI y SRQ. Conclusiones: El déficit cognitivo de esos ancianos fue el factor predictivo para la sobrecarga y disconfort emocional de sus cuidadores. Conocer la reducción de la capacidad cognitiva relacionada a la sobrecarga del cuidador es indispensable para preservar su salud.

Descriptores: Anciano; Cuidadores; Estrés psicológico; Trastornos del conocimiento

\footnotetext{
* Study extracted from the doctoral thesis entitled: "Burden of family caregivers of elderly people in the community" - defended at College of Nursing, University of São Paulo at Ribeirão Preto - USP -- Ribeirão Preto (SP), Brazil.

1 Associate Professor, Universidade de Brasilia - UNB - Brasilia (DF), Brazil. Graduate Nursing Program, Brasília (DF), Brazil.

${ }^{2}$ PhD candidate, Graduate Program in Nursing Fundamental, College of Nursing, University of São Paulo at Ribeirão Preto - USP -Ribeirão Preto, (SP), Brazil.

${ }^{3}$ PhD in Physics Applied to Medicine and Biology. University of São Paulo at Ribeirão Preto, College of Nursing - USP - Ribeirão Preto, (SP), Brazil.

${ }^{4}$ Professor, General and Specialized Nursing Department, College of Nursing, University of São Paulo at Ribeirão Preto - USP - Ribeirão Preto, (SP), Brazil.

${ }_{5}^{5}$ Professor, General and Specialized Nursing Department, College of Nursing, University of São Paulo at Ribeirão Preto - USP - Ribeirão Preto, (SP), Brazil.

${ }^{6}$ Full Professor, General and Specialized Nursing Department, College of Nursing, University of São Paulo at Ribeirão Preto - USP - Ribeirão Preto, (SP), Brazil.
} 


\section{INTRODUCTION}

Given the considerable increase in the number of older people in recent decades in Brazil and the country's lack of infrastructure to receive this population, it is crucial to identify its specific needs, especially with regard to health.

Demographic data indicate that the world elderly population will increase by $160 \%$ between 1980 and 2020, i.e. from 375 to 975 million individuals. About $80 \%$ of this increase will take place in developing countries $^{(1)}$. In Brazil, the number of elderly people 60 years old or older increased from 14.8 million in 1999 to approximately 20.6 million (11\% of the population) in 2009. In 1999, the Brazilian population over 70 years of age was 6.4 million people $3.9 \%$ of the total population) while, in 2009, the population in this age group reached 9.3 million, which corresponds to $5.1 \%$ of the Brazilian population.

Given this demographic transition, the epidemiological panorama changes and conditions associated with the aging process and non-transmissible chronic diseases become prevalent in the population. Consequently, the main concern is to avoid the situation where individuals reach old age with one or more diseases that limit their daily lives and make them dependent on others ${ }^{(3)}$. The achievement of such a goal, however, is threatened when elderly individuals face health problems that cause loss of autonomy and independence. Among the most devastating problems is cognitive impairment ${ }^{(4)}$.

Cognitive impairment among older adults consists of generalized and mild mental slowness and loss of precision, which progresses with age, when compared to younger individuals ${ }^{(5)}$. Its onset is associated with various causes, such as impaired memory due to the use of medication (especially benzodiazepines, neuroleptics and antidepressants), emotional response, in particular depression, and mainly due to dementia ${ }^{(4)}$. Dementia can be considered the leading cause of disability and dependence in old age, increasing costs and requiring constant care, mainly provided by a family caregiver, throughout the disease's progression.

Assuming the task of providing dignified care to an older adult with cognitive deficit has been a duty mainly of the family, which often does not have appropriate training, knowledge or support to play such a role. The rise of positive and negative feelings, psychological conflicts, distress, fear and insecurity, is common with the progression of the disease ${ }^{(()}$.

Research addressing caregivers of older adults with cognitive impairment in the community is scarce. Hence, this study highlights aspects of the lives of older adults with cognitive deficit living in the community and their respective family caregivers.
This study evaluates emotional distress and caregiver burden experienced by those caring for elderly individuals with cognitive deficit who live in the community and risk factors associated with the characteristics of older adults and which may contribute to caregiver burden.

\section{METHODS}

This observational, descriptive and cross-sectional study applied the Zarit Burden Interview (ZBI) and the Self-Reporting Questionnaire (SRQ) to verify the level of emotional distress and caregiver burden in individuals caring for older adults with cognitive impairment.

\section{Participants and ethical considerations}

Two-stage cluster sampling was used. In the first stage, Census Sectors were considered the Primary Sampling Unit (PSU). These sectors are defined by the Brazilian Census Bureau according to operational criteria and include between 250 and 300 households in urban areas. Hence, 30 census sectors were randomly drawn from the 600 sectors in the city, with probability proportional to the number of households. The second stage included visiting a fixed number of households, aiming to ensure a self-weighted sampling; the street and block where the process began were randomly drawn. A minimum of 110 households in each sector was visited in order to reach the number of older adults in the sample.

During the household visits, the older individuals and their respective caregivers were invited to participate in the study and those who consented and met the inclusion criteria signed free and informed consent forms in duplicate.

The sampling criteria included being 65 years old or older, either gender, residents of Ribeirão Preto, São Paulo, Brazil, living by themselves or with relatives in the community and having an unpaid family caregiver.

The sample was composed of 70 older adults with cognitive impairment and 70 caregivers. The study was initiated after approval from the Research Ethics Committee at the University of São Paulo at Ribeirão Preto (process number 0884/2008).

\section{Procedure}

Data collection was carried out between January and July 2009. The following data were collected when assessing the elderly:

Questionnaire addressing social profile: age, gender, marital status, income of the older adult and family income, type of income, years of retirement, education, and with whom the individual lived.

Mini-Mental State Examination (MMSE): scale developed $^{(7)}$ in the United States to aid in the investigation of potential cognitive deficits in individuals at risk of developing dementia. It was translated and validated 
in $\mathrm{Brazil}^{(8)}$ and the score ranges from 0 to 30, with the following cutoff points: below 13 for illiterate individuals, 18 for individuals with low and average schooling ( 1 to 4 years and 5 to 8 years) and 26 for those with a high level of schooling (more than 9 years). Because the Brazilian population has very diversified levels of education, which is low among older adults, the stratified cutoff points reduced diagnosis errors since educational level is the most important factor considered in the MMSE.

The following instruments were used to evaluate the caregivers:

Questionnaire to characterize caregivers: allows identifying caregivers of older adults with cognitive impairment in the following aspects: gender, age, marital status, kinship, knowledge concerning the disease, whether the individual attended a formal course on care, hours dedicated to care, and support activities.

Zarit Burden Interview (ZBI): this scale ${ }^{(9)}$ was translated and validated into the Brazilian culture ${ }^{(10)}$. Its 22 items evaluate the perceived impact of providing care to physical and emotional health, social activities and financial condition. Answers to the 22 items are provided on a five-point scale that describes how each statement affects the person. The total score is obtained by adding up all items and ranges from 0 to 88 .

Self-Reporting Questionnaire (SRQ-20): this instrument ${ }^{(11)}$ was validated in Brazil ${ }^{(12)}$ and allows detecting emotional distress in the general population. Scores range from 0 to 20 and the suggested cutoff point is $7 / 8$, based on the Brazilian study to distinguish cases with emotional disorders.

\section{Data analysis}

A spreadsheet was developed in Excel with a codebook and two spreadsheets were used for double entry validation. Data analysis was carried out using the Statistical Package for the Social Sciences 15.0 (SPSS Inc., Chicago, IL, USA). The averages of continuous variables were statistically analyzed by Student's $t$ test and one-factor ANOVA was used to compare more than two groups. Spearman's correlation coefficient was computed between ordered and quantitative variables, and Pearson's correlation was used among quantitative variables. The statistical significance was fixed at $\mathrm{p}<0.05$. The correlations were considered weak $(r<0.3)$, moderate $(0.3 \leq r<0.7)$ or strong $(r \geq 7)$.

\section{RESULTS}

Table 1 presents the socio-demographic characteristics of older adults with cognitive deficit. Among the 70 studied individuals, most were 80 years old or older, mainly women, who reported not having partners, while most men reported having partners. Near $26 \%$ reported living either with their spouses, children or in-laws. The average income was U\$1,728.00.
Table 1 - Distribution of older individuals with cognitive deficit living in the community of Ribeirão Preto, SP, Brazil according to age, gender, marital status, schooling, income, and with whom they lived - 2009

\begin{tabular}{lcccc}
\hline $\begin{array}{l}\text { Older adults } \\
\text { profile }\end{array}$ & $\begin{array}{c}\text { Female } \\
\mathbf{n}=\mathbf{5 3} \\
\mathbf{n}(\mathbf{\%})\end{array}$ & $\begin{array}{c}\text { Male } \\
\mathbf{n}=\mathbf{1 7} \\
\mathbf{n}(\mathbf{\%})\end{array}$ & $\begin{array}{c}\text { Total } \\
\mathbf{n}=\mathbf{7 0} \\
\mathbf{n}(\%)\end{array}$ & p-value \\
\hline $\begin{array}{l}\text { Age Range } \\
\text { Average(SD) }\end{array}$ & $86.1(7.7)$ & $78.9(7.5)$ & $84.3(8.2)$ & $<0.001^{*}$ \\
$65-69$ old & $3(5.7)$ & $3(176)$ & $6(8.6)$ & \\
$70-74$ old & $2(3.8)$ & $2(118)$ & $4(5.7)$ & \\
$75-79$ old & $7(13.2)$ & $5(294)$ & $12(17.1)$ & \\
80 old or older & $41(77.4)$ & $7(412)$ & $48(68.6)$ &
\end{tabular}

Marital status

Partner

$<0.001 * *$

$\begin{array}{lccc}\text { Yes } & 3(5.7) & 12(70.6) & 15(21.4) \\ \text { No } & 50(94.3) & 5(29.4) & 55(78.6) \\ \begin{array}{l}\text { Education } \\ \text { Average(SD) }\end{array} & 3.09(4.2) & 4.6(4.3) & 4.3(4.3)<0.001^{*} \\ \begin{array}{l}\text { Illiterate } \\ 1 \text { to } 4 \text { years }\end{array} & 25(47.2) & 5(29.4) & 30(42.9) \\ 5 \text { to } 8 \text { years } & 3(5.7) & 2(11.8) & 5(7.1) \\ 9 \text { to } 11 \text { years } & 2(3.8) & 2(11.8) & 4(5.7) \\ 12 \text { years or } & 0(0) & 3(17.6) & 3(4.3)\end{array}$

With whom the older adults lived

$<0.001 * *$

\begin{tabular}{|c|c|c|c|}
\hline Alone & $6(11.3)$ & $1(5.9)$ & $7(10)$ \\
\hline $\begin{array}{l}\text { Only with } \\
\text { spouse }\end{array}$ & $2(3.8)$ & $4(23.5)$ & $6(8.6)$ \\
\hline $\begin{array}{l}\text { Spouse and } \\
\text { children }\end{array}$ & $0(0)$ & $1(5.9)$ & $1(1.4)$ \\
\hline $\begin{array}{l}\text { Spouse, } \\
\text { children and } \\
\text { in-laws }\end{array}$ & $12(22.6)$ & $6(35.6)$ & $18(25.7)$ \\
\hline $\begin{array}{l}\text { Only with } \\
\text { children }\end{array}$ & $5(9.4)$ & $1(5.9)$ & $6(8.6)$ \\
\hline $\begin{array}{l}\text { Three- } \\
\text { generation } \\
\text { arrangements }\end{array}$ & $8(15.1)$ & $0(0)$ & $8(11.4)$ \\
\hline $\begin{array}{l}\text { Intra- } \\
\text { generation } \\
\text { arrangements }\end{array}$ & $1(1.9)$ & $1(5.9)$ & $2(2.9)$ \\
\hline $\begin{array}{l}\text { Only with } \\
\text { grandchildren }\end{array}$ & $2(3.8)$ & $1(5.9)$ & $3(4.3)$ \\
\hline $\begin{array}{l}\text { Other than } \\
\text { family }\end{array}$ & $3(5.7)$ & $0(0)$ & $3(4.3)$ \\
\hline Others & $13(24.5)$ & $2(11.8)$ & 15 (21.4) \\
\hline TOTAL & $52(75.7)$ & $17(24.3)$ & 70 100) \\
\hline
\end{tabular}

* Student's t test

** $\chi^{2}$ association 
The profile of the caregivers of older adults with cognitive impairment is presented in Table 2. Most of the individuals were 60 years old or younger, had a partner, had from 1 to 4 years of schooling, were the older adults' children or in-laws, lived with the older adults, and reported knowledge concerning the care activity. The following averages were found in the analysis of caregiver burden and emotional distress: $30.3( \pm 17.3)$ and $6.2( \pm 3.2)$, respectively.

Table 2-Distribution of caregivers according to age, gender, marital status, schooling, kinship, whether they lived with the older adult, knowledge concerning the care activity, average ages, Zarit Burden Interview (ZBI) and SRQ related to the caregiver's gender - 2009

\begin{tabular}{|c|c|c|c|c|}
\hline $\begin{array}{l}\text { Caregivers' } \\
\text { profile }\end{array}$ & $\begin{array}{c}\text { Female } \\
\mathrm{n}=59 \\
\mathrm{n}(\%)\end{array}$ & $\begin{array}{l}\text { Male } \\
\mathrm{n}=11 \\
\mathrm{n}(\%)\end{array}$ & $\begin{array}{c}\text { Total } \\
\mathrm{n}=70 \\
\mathrm{n}(\%)\end{array}$ & p-value \\
\hline $\begin{array}{l}\text { Age range } \\
\text { A(SD) }\end{array}$ & $54.1(12.5)$ & $64.3(13.6)$ & $55.7(13.4)$ & $0.032 *$ \\
\hline 59 or younger & $44(74.5)$ & $5(45.5)$ & $49(70)$ & \\
\hline 60 or older & $15(25.4)$ & $6(54.5)$ & $21(30)$ & \\
\hline Partner & & & & $0.004 * *$ \\
\hline Yes & $44(74.5)$ & $2(18.2)$ & $46(65.7)$ & \\
\hline No & $15(25.4)$ & $9(81.8)$ & $24(34.7)$ & \\
\hline Education & & & & $<0.001^{* *}$ \\
\hline Illiterate & $2(3.4)$ & $0(0)$ & $2(2.9)$ & \\
\hline 1 to 4 years & $26(44.1)$ & $5(45.5)$ & $32(45.7)$ & \\
\hline 5 to 8 years & $17(28.8)$ & $3(27.3)$ & $20(28.6)$ & \\
\hline 9 to 11 years & 11 (18.6) & $2(18.2)$ & 13 (18.6) & \\
\hline $\begin{array}{l}12 \text { years or } \\
\text { more }\end{array}$ & $3(5.1)$ & $1(9.1)$ & $4(5.7)$ & \\
\hline Kinship & & & & $0.596^{* *}$ \\
\hline Spouse & 7 (11.9) & $1(9.1)$ & 8 (11.4) & \\
\hline Children & $35(59.3)$ & $5(45.5)$ & $40(57.1)$ & \\
\hline In-laws & $6(10.2)$ & $3(27.3)$ & $9(12.9)$ & \\
\hline Grandchildren & $4(6.8)$ & $0(0)$ & $4(5.7)$ & \\
\hline Others & 7 (11.9) & $2(18.2)$ & $9(12.9)$ & \\
\hline $\begin{array}{l}\text { Live with the } \\
\text { older adult }\end{array}$ & & & & $0.130^{* *}$ \\
\hline Yes & $45(76.3)$ & $11(100)$ & $56(80)$ & \\
\hline No & $14(23.7)$ & $0(0)$ & $14(20)$ & \\
\hline $\begin{array}{l}\text { Knowledge } \\
\text { concerning care }\end{array}$ & & & & $0.004^{* *}$ \\
\hline Yes & $58(98.3)$ & $10(90.9)$ & $68(97.1)$ & \\
\hline No & $1(1.7)$ & $1(9.1)$ & $2(2.9)$ & \\
\hline Total & $59(84.3)$ & $11(15.7)$ & $70(100)$ & \\
\hline $\begin{array}{l}\text { ZBI - Average } \\
\text { (SD) }\end{array}$ & $30.6(17.2)$ & $28.6(17.8)$ & $30.3(17.3)$ & $0.079 *$ \\
\hline $\begin{array}{l}\text { SRQ - Average } \\
\text { (SD) }\end{array}$ & $6.6(4.3)$ & $3.8(2.5)$ & $6.2(3.2)$ & $0.003 *$ \\
\hline
\end{tabular}

* Student's $t$ test

** $\chi 2$ association
The linear regression analysis presented significant values, though close to the critical value $(\beta=-0.046$; $\mathrm{p}=0.056)$ for symptoms of emotional distress and burden related to the fact that the older adult was cognitively impaired.

\section{DISCUSSION}

The study showed that most of the individuals in the studied population $(\mathrm{n}=70)$ were women and the average age was 84.3 years old $( \pm 8.2)$, minimum age was 65 years old and maximum was age was 103 years old, while the average age of women was higher than that of men and higher than the average found in other studies ${ }^{(6,13,14)}$.

In terms of education, most participants were either illiterate or had up to four years of education; men displayed a higher average $(4.6 ; \pm 4.3)$ of years of education compared to women $(3.1 ; \pm 4.2)$, in agreement with data found in another Brazilian study ${ }^{(15,16)}$. Education is sometimes considered a protective factor against pathological cognitive aging. More experiences with activities that demand different cognitive functions, such as reading, arithmetic, logic, abstraction, and planning, may positively affect and help to preserve cognitive function in old age.

Older adults without a partner were mostly women, while most men had partners. Another study ${ }^{(17)}$ evaluated the relationship between cognitive capacity and ability to perform activities of daily living in 427 older adults aged between 85 and 95 years old without dementia in Italy, and showed that high cognitive capacity is associated with not being married. The authors argued that the studied women were in general married to older men and were burdened by care provided to their husbands, which negatively affected cognition, while the single participants who presented high cognitive capacity were more engaged in diverse aspects of life, which would benefit cognition.

A considerable number of the older adults with low cognitive performance reported living either with their spouses, children or in-laws. A noteworthy fact is that seven $(10 \%)$ of these individuals lived alone. Loneliness has been related to depression, which might be explained by the fact that some older adults with cognitive deficit lived alone ${ }^{(18)}$.

Even though the need to investigate the prevalence of cognitive impairment in older adults living in the community is well known, studies addressing the subject are rare in Brazil and other developing countries. Hence, there is little consensus about the impact of this neurological condition on the lives of older adults and their families.

Most of the interviewed caregivers recognized themselves as family caregivers, while women are the traditional caregivers, in agreement with both the national and international literature ${ }^{(6,13,14,19,20)}$. This study's findings reinforce women's historically determined social role in 
which they are expected to look after the house, children and husband. The fact that women in the past did not have activities outside home explains, at least partially, their availability and knowledge to care for the family.

Although data indicate a larger number of female caregivers, increased participation of men of different ages and kinship levels (spouses, children and grandchildren), is observed in care provided to older adults. An international study ${ }^{(21)}$ revealed that $39 \%$ were male caregivers.

Similar to other studies, mainly Brazilian ones ${ }^{(6,14,19,22)}$, the average age of caregivers was 55.7 years old, though lower than the age reported in an international study ${ }^{(18)}$. Life expectancy in developed countries is higher than in developing countries, which might explain the higher average age of caregivers compared to that found in Brazilian studies.

Most of the caregivers lived with the older adults, totaling $80 \%$ of the sample. Most national and international studies corroborate such findings ${ }^{(6,13,14,20)}$. This fact can be seen as a benefit for older adults receiving care, since their care needs can be promptly met. For the caregivers, however, it may be seen as a negative factor, given the intense exposure to effects that accrue from the care process experienced daily, which may generate high levels of stress.

In terms of schooling, most caregivers had from one to four years of education, i.e. a low educational level. This result is below that reported by another Brazilian study addressing caregivers ${ }^{(22)}$. Low education might explain why these individuals became caregivers. Formal job requirements prevent individuals with low levels of education from entering the job market. Hence, these individuals are more likely to dedicate themselves to housework and care activities.

Regarding the caregivers' ages, $30 \%$ of the sample were 60 years old or older and therefore, these individuals experienced a period in which access to schools was difficult, added to the fact that the families used to include children in household activities, especially those in rural areas. Nonetheless, low education is also observed among the remaining $70 \%$ of the sample despite their younger age. A sample survey carried out with older individuals, 60 years or older, living in the community, revealed that a low educational level is still a social problem ${ }^{()}$.

The evaluation of burden carried out through ZBI (Cronbach's alpha 0.642) revealed that caregivers had great difficulty understanding the scale, since most of these individuals were classified as having a low educational level. The average burden was 30.3. No significant differences were found among levels of burden when comparing male and female caregivers.

International studies, which utilized the ZBI and addressed caregivers of older adults with dementia, found higher averages, such as the prospective study ${ }^{(14)}$ carried out in Spain. It analyzed the ability of ZBI to identify exhaustion in 66 caregivers of older adults with dementia and risk factors of caregiver burden and found an average of 74.6. Another prospective study evaluated 141 elderly individuals (76.6\% with dementia) and informal caregivers (family and friends) at a geriatric service in Ottawa, Canada. The caregivers were evaluated using ZBI and short version ZBI (12 items) and found average scores of 31.3 and 15.9 respectively ${ }^{(23)}$.

A national cross-sectional study investigated 49 demented older adults and their caregivers in a university hospital in São Paulo, Brazil, and found higher burden averages. The caregivers were evaluated using SRQ and $\mathrm{ZBI}$ and the average burden was $32.4^{(24)}$.

Caregiver burden was correlated with the clinical characteristics of demented patients in a retrospective study analyzing the medical files of older adults in the Cognitive Disorders Center of a university hospital in São Paulo, Brazil and the average score obtained by 67 caregivers on the ZBI was $32^{(13)}$. Another cross-sectional study evaluated 83 caregivers of demented older adults in a university outpatient clinic in Belo Horizonte, Brazil and obtained an average score of 31.4 on the $\mathrm{ZBI}^{(20)}$.

Increased caregiver burden is observed when it is related to cognitive deficit caused by dementia. The greater the autonomy loss of older adults, the greater is the demand for care, which consequently overloads caregivers who provide care routinely. Similarly, studies addressing demented older adults revealed that behavior disorders caused by the disease are one of the leading causes of burden ${ }^{(4,14,23,24)}$.

One of the purposes of care provided to demented patients is mainly related to keeping them physically safe, and reducing their anxiety and agitation. Caring for patients whose anxiety and agitation are under control alleviates caregiver burden ${ }^{(14)}$.

In this study, the SRQ (Cronbach's alpha 0.852) was used in addition to the caregiver burden scale, evaluating physical and psychological problems that characterize emotional distress in order to better understand the fatigue experienced by caregivers. The average score of the studied caregivers was 6.2 , indicating that they did not experience emotional distress.

The multiple linear regression revealed that cognitive deficit can be considered a risk factor for caregiver burden. It is common to find caregivers suffering from depression and isolation in response to prolonged exposure to physical and emotional weariness, which are potential stressors ${ }^{(21)}$.

The problems faced by older adults with cognitive deficit and their caregivers are multidimensional and require that health professionals look at care provided to these individuals from a new perspective in order to contemplate the individuals' wholeness and support healthcare delivery. 


\section{CONCLUSIONS}

The instruments used in this study proved to be reliable for the studied population. Greater attention, however, should be paid to the reading and interpretation of the burden scale questions when applied to caregivers with low levels of education. Emotional distress was also evaluated to complement the burden evaluation: signs and symptoms related to anxiety and depression were also investigated.

The entire society, including social actors, governmental and non-governmental organizations, need to join in

\section{REFERENCES}

1. Kalache A, Veras RP, Ramos LR. [The ageing of the world's population. A new challenge]. Rev Saúde Pública. 1987;21(3): 200-10. Portuguese.

2. Instituto Brasileiro de Geografia e Estatística. Censo demográfico 2010. Resultados do universo [Internet] [citado 2010 Dez q]. Disponível em: http:/ /www.ibge.gov.br/home/ estatistica/populacao/censo2010/default_resultados_ universo.shtm

3. Marques S, Rodrigues RA, Kusumota L. Cerebrovascular accident in the aged: changes in family relations. Rev Latinoam Enferm. 2006; 14(3):364-71.

4. Huang CY, Sousa VD, Perng SJ, Hwang MY, Tsai CC, Huang $\mathrm{MH}$, et al. Stressors, social support, depressive symptoms and general health status of Taiwanese caregivers of persons with stroke or Alzheimer's disease. J Clin Nurs. 2009; 18(4):502-11.

5. Argimon II, Stein LM. [Cognitive abilities in older seniors: a longitudinal study]. Cad Saúde Pública. 2005; 21(1):64-72. Portuguese

6. Gratão AC, Vale FA, Roriz-Cruz M, Haas VJ, Lange C, Talmelli LF, et al. The demands of family caregivers of elderly Individuals with dementia. Rev Esc Enferm USP. 2010; 44(4): 873-80.

7. Folstein MF, Folstein SE, McHugh PR. "Mini-mental state". A practical method for grading the cognitive state of patients for the clinician. J Psychiatr Res. 1975; 12(3):189-98.

8. Bertolucci PH, Brucki SM, Campacci SR, Juliano Y. The Mini-Mental State Examination in an outpatient population: influence of literacy. Arq Neuropsiquiatr. 1994; 52(1):1-7.

9. Zarit SH, Zarit JM. The memory and behavior problems checklist 1987R and the burden interview (technical report). University Park (PA): Pennsylvania State University; 1987.

10. Scazufca M. Brazilian version of the Burden Interview Scale for the assessment of burden of care in carers of people with mental illnesses. Rev Bras Psiquiatr. 2002; 24(1):12-7.

11. Harding TW, Arango MV, Baltazar J, Climent CE, Ibrahim $\mathrm{HH}$, Ladrido-Ignacio L, et al. Mental disorders in primary health care: a study of their frequency and diagnosis in four developing countries. Psychol Med. 1980; 10(2):231-41.

12. Mari JJ, Williams P. A validity study of a psychiatric screening questionnaire (SRQ-20) in primary care in the city of São Paulo. Br J Psychiatry. 1986; 148:23-6.

13. Cassis SV, Karnakis T, Moraes TA, Curiati JA, Quadrante order to enable effective social engagement to improve the living conditions of older adults. The Government Plan Actions establish guidelines for care, however, state and city health services, universities, non-governmental organizations and other networks should organize and devise formal and informal interventions directed to the elderly and their families. Further studies are needed to enable a better understanding of the needs of family caregivers of older adults with cognitive impairment. Moreover, guided studies may also contribute to health services and institutions in order to meet specific demands of this population.

AC, Magaldi RM. [Correlation between burden on caregiver and clinical characteristics of patients with dementia]. Rev Assoc Méd Bras. 2007; 53(6):497-501. Portuguese.

14. Gort AM, Mingot M, Gomez X, Soler T, Torres G, Sacristán $\mathrm{O}$, et al. Use of the Zarit scale for assessing caregiver burden and collapse in caregiving at home in dementias. Int J Geriatr Psychiatry. 2007; 22(10): 957-62.

15. Ribeiro PC, Oliveira BH, Cupertino AP, Neri AL, Yassuda MS. Performance of the elderly in the CERAD cognitive battery: relations with socio-demographic variables and perceived health]. Psicol Reflex Crít. 2010; 23(1):102-5. Portuguese.

16. Ferreira PC, Tavares DM, Rodrigues RA. Sociodemographic characteristics, functional status and morbidity among older adults with and without cognitive decline. Acta Paul Enferm. 2011; 24(1):29-35.

17. Steen G, Sonn U, Hanson AB, Steen B. Cognitive function and functional ability. A cross-sectional and longitudinal study at ages 85 and 95 in non-demented population. Aging (Milano). 2001; 13(2):68-77.

18. O'Rourke N, Tuokko HA. Caregiver burden and depressive symptomatology: The association between constructs over time. Clin Gerontol. 2004; 27(4):41-53.

19. Taub A, Andreoli SB, Bertolucci PH. Dementia caregiver burden: reliability of the Brazilian version of the Zarit caregiver burden interview. Cad Saúde Pública. 2004; 20(2):372-6.

20. Fialho PP, Koenig AM, Santos EL, Guimarães HC, Beato RG, Carvalho VA, et al. Dementia caregiver burden in a brazilian sample: association to neuropsychiatric symptoms. Dement Neuropsychol. 2009; 3(2):132-5.

21. Lund M. Caregiver, take care. Geriatr Nurs. 2005; 26(3): 152-3.

22. Amendola F, Oliveira MA, Alvarenga MR. [Quality of life of family caregivers of patients dependent on the family health program]. Texto \& Contexto Enferm. 2008; 17(2):266-72. Portuguese.

23. Aminzadeh F, Byszewski A, Dalziel WB. A prospective study of caregiver burden in an outpatient comprehensive geriatric assessment program. Clin Gerontologists. 2006; 29(4): 47-60.

24. Garrido R, Menezes PR. [Brazil is aging: good and bad news from an epidemiological perspective]. Rev Bras Psiquiatr. 2004; 24 Supl 1: 3-6. Portuguese. 